Biol. Stud. 2016: 10(2); 203-214 • DOI: https://doi.org/10.30970/sbi.1002.486 www.http://publications.Inu.edu.ua/journals/index.php/biology

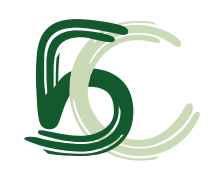

УДК 547.458:547.455.65 ФРУКТАНИ: ХІМІЧНА СТРУКТУРА, БІОЛОГІЧНІ ВЛАСТИВОСТІ
ТА МЕТАБОЛІЗМ КИШКОВОЮ МІКРОФЛОРОЮ

М. Я. Сабат ${ }^{1}$, Р. Я. Іскра ${ }^{2}$

${ }^{1}$ Львівський національний університет ветеринарної медицини та біотехнологій імені С. З. Гжицького, вул. Пекарська, 50, Львів 79010, Україна

${ }^{2}$ Інститут біології тварин НААН України вул. В. Стуса, 38, Львів 79034, Україна e-mail: Mariana.sabat@gmail.com

В огляді представлено дані зарубіжних авторів щодо хімічної структури та біологічних властивостей фруктанів. Показано результати окремих досліджень впливу різних фрруктанів на представників кишкової мікрофлори лабораторних тварин і людини. Проте $€$ недостатньо інформації про метаболізм фруктанів в організмі сільськогосподарських тварин, зокрема жуйних, і їх можливий вплив на процеси травлення цих тварин. У статті розкрито важливість фрруктанів як компонентів раціону харчування людини і тварин. Встановлено, що вони впливають на метаболізм і фрізіологічний стан макроорганізму, однак збільшена їхня кількість у кишечнику спричиняє негативні ефекти. Фруктоолігосахариди й інулін стимулюють ріст біфрідобактерій кишечника. Проте штами біфідобактерій тваринного походження ростуть на середовищі з інуліном швидше, порівняно зі штамами, ізольованими від людини. Дослідження впливу перорально введеного фрруктоолігосахариду дали змогу виявити стимулюючу дію цих цукрів на ріст біфрідобактерій у кишечнику лабораторних тварин і людини. Проте ці дані не узгоджуються з ефектом фруктоолігосахаридів для інших видів бактерій. Запропоновано гіпотезу, що споживання фруктанів із подальшим збільшенням біфрідобактерій спричиняє зменшення кількості клостридій. У подальшому дослідженні буде проаналізовано вплив фруктанів на інших представників кишкової мікрофрлори тварин.

Ключові слова: фруктани, метаболізм, кишкова мікрофрлора, інулін, леван.

Фруктани - це полімери молекул фруктози зі змінним типом зв'язку та довжиною, з глюкозними залишками або без них. Фруктани розрізняють за молекулярною будовою відповідно до ступеня полімеризації, розгалуженості й типу зв'язків між залишками фрруктози.

Найважливішими і комерційно доступними фруктанами є інулін і фрруктоолігосахариди (ФОС). Вони розглядаються як функціональні харчові інгредієнти, оскільки впливають на фізіологічні та біохімічні процеси у тварин і людини, що

ISSN 1996-4536 (print) • ISSN 2311-0783 (on-line) • Біологічні Студії / Studia Biologica • 2016 • Том 10/№2 • C. 203-214 
зумовлює покращення їхнього здоров'я і зниження ризику розвитку багатьох захворювань. Експериментальні дослідження показали, що їх застосування як біфідогенних агентів стимулює імунну систему організму, зменшує кількість патогенних бактерій у кишечнику, знижує ризик розвитку остеопорозу за рахунок збільшення засвоєння мінеральних речовин, особливо кальцію, знижує ризик розвитку атеросклерозу завдяки зменшенню синтезу триацилгліцеролів і жирних кислот у печінці, знижуючи їхній рівень у сироватці крові. Ці фрруктани модулюють гормональний рівень інсуліну і глюкагону, регулюючи тим самим вуглеводний і ліпідний обміни, знижують рівень глюкози у крові; вони також ефективні у зниженні рівня сечовини і сечової кислоти в крові, підтримуючи таким чином баланс азоту. Інулін і ФОС також знижують частоту розвитку раку товстої кишки. Біохімічні основи цих ефектів інуліну і ФОС висвітлені у цьому огляді. Завдяки великій кількості позитивних ефректів фрруктанів на покращення здоров'я людини і тварин, їх широко застосовують у різних типах продуктів харчування, таких як кондитерські вироби, фруктові наповнювачі, молочні десерти, йогурти, свіжий сир, шоколад, морозиво і соуси. Проте у літературі $€$ недостатньо інформації про метаболізм фрруктанів в організмі сільськогосподарських тварин і їх можливий вплив на процеси травлення цих тварин, що ляже в основу наших майбутніх досліджень.

Хімічна структура фруктанів. Фруктани - це полісахариди, побудовані зі залишків D-фрруктози. Ці цукри ще називають глюкофруктанами, вони нагромаджуються у рослинних організмах у різних формах [2]. Їх також виявляють у клітинах зелених водоростей, грибів і бактерій [29-32]. Функціональність різних структур фруктанів досі не встановлена. Відмінності у довжині їх карбонового ланцюга $€$ результатом не лише таксономічної зміни, але також наслідком впливу навколишнього середовища, життєвого циклу, часу й умов зберігання.

Фруктани - продукти трансфруктозилювання сахарози, тому кожна молекула містить один залишок D-глюкози, який не виявляє відновлювальних властивостей. В утворенні глікозидних зв'язків фруктанів беруть участь лише первинні групи $\mathrm{OH}$. Молекула сахарози містить три первинні гідроксили, тому можливе утворення різних трисахаридів, які $€$ попередниками трьох типів фрруктанів: 1 - ізокестоза (І-кестоза); 2 - кестоза (6-кестоза); 3 - неокестоза. Послідовне приєднання залишків D-фруктофруранози до 1-кестози зв'язками $2 \rightarrow 1$ дає інулін, а до фрруктозного залишку 6-кестози зв'язками $2 \rightarrow 6$ - фрлеїн (у рослинах) і леван (у бактеріях). Полісахариди на базі неокестози містять зв'язок $2 \rightarrow 1$ між залишками D-фруктофуранози, але трапляються рідко. Біосинтез фруктанів тісно пов'язаний з метаболізмом сахарози, яка слугує як донором, так і акцептором залишків D-фруктофуранози. Фруктани утворюють гомологічний ряд, кожний член якого відповідає основній формулі G F [F]n, де G-F - цукрова група, [F] - залишок фрруктофруранози.

Гомологічний ряд фрруктанів починається з найнижчого гомолога сахарози (n = 0), а не з фруктози. Наступним є трисахарид, далі йде тетрасахарид. Кожний попередній олігосахарид відрізняється від наступного на один залишок фруктози. Згідно з номенклатурою олігосахаридів їх називають (фруктозил)-сахароза,

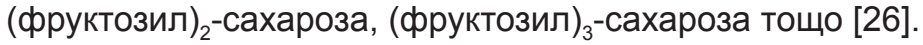

Фруктополісахариди, що складаються зі субодиниць глюкози і фруктози, поділяють на типи: ФОС та інулін. Єдина відмінність між ФОС та інуліном - це довжина ланцюга полімеру. Фруктоолігосахариди - це фруктани з короткою довжиною ланцюга.

ISSN 1996-4536 (print) • ISSN 2311-0783 (on-line) • Біологічні Студії / Studia Biologica • 2016 • Том 10/№2 • С. 203-214 
Ступінь полімеризації (СП) - це кількість моносахаридних залишків у вуглеводах; у фруктанів рослин він перебуває в межах приблизно від 3 до 200 одиниць фрруктози. Більшість бактеріальних фрруктанів мають дуже високий СП (до 100000 одиниць) [46]. У літературі є різні визначення СП ФОС. Вважають, що цей показник може бути від 2 до 10 [1], що характерне для олігосахаридів [18], або меншим [37]. Проте інші дослідники вважають, що СП ФОС становить від 2 до 20 [32-38].

Застосовуючи аналітичні методи, вміст вуглеводів визначають на основі нерозчинності полісахаридів у водному етанолі (80\%). Розподіл вуглеводів (у тому числі фрруктанів) на моносахариди (СП 1), олігосахариди (СП 2-10) і полісахариди (СП > 11) у практиці є менш значним [12, 39].

Найважливішим і комерційно доступним фрруктаном є інулін (містить 3-60 одиниць). Інулін - це фруктан або глюкофруктан, який отримав назву від рослини оман високий (Inula helenium), з якої був уперше виділений. Серед фруктанів найпоширенішою фрормою $\epsilon$ інулін, у якого залишки $\beta$-D-фрруктофруранози зв'язані $1 \rightarrow 2$ глі-

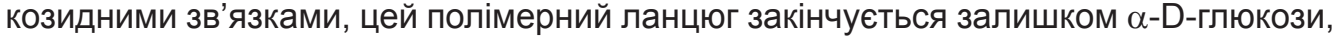
що не окиснюється (рис. 1). У рослинах синтезується із сахарози внаслідок поступового трансфруктозилювання [4-6]. В інуліні, екстрагованому з коренів цикорію, більшість молекул мають залишок глюкози $\left(\mathrm{GF}_{\mathrm{n}}\right)$, проте невелика частина молекул цих залишків не містить [5].

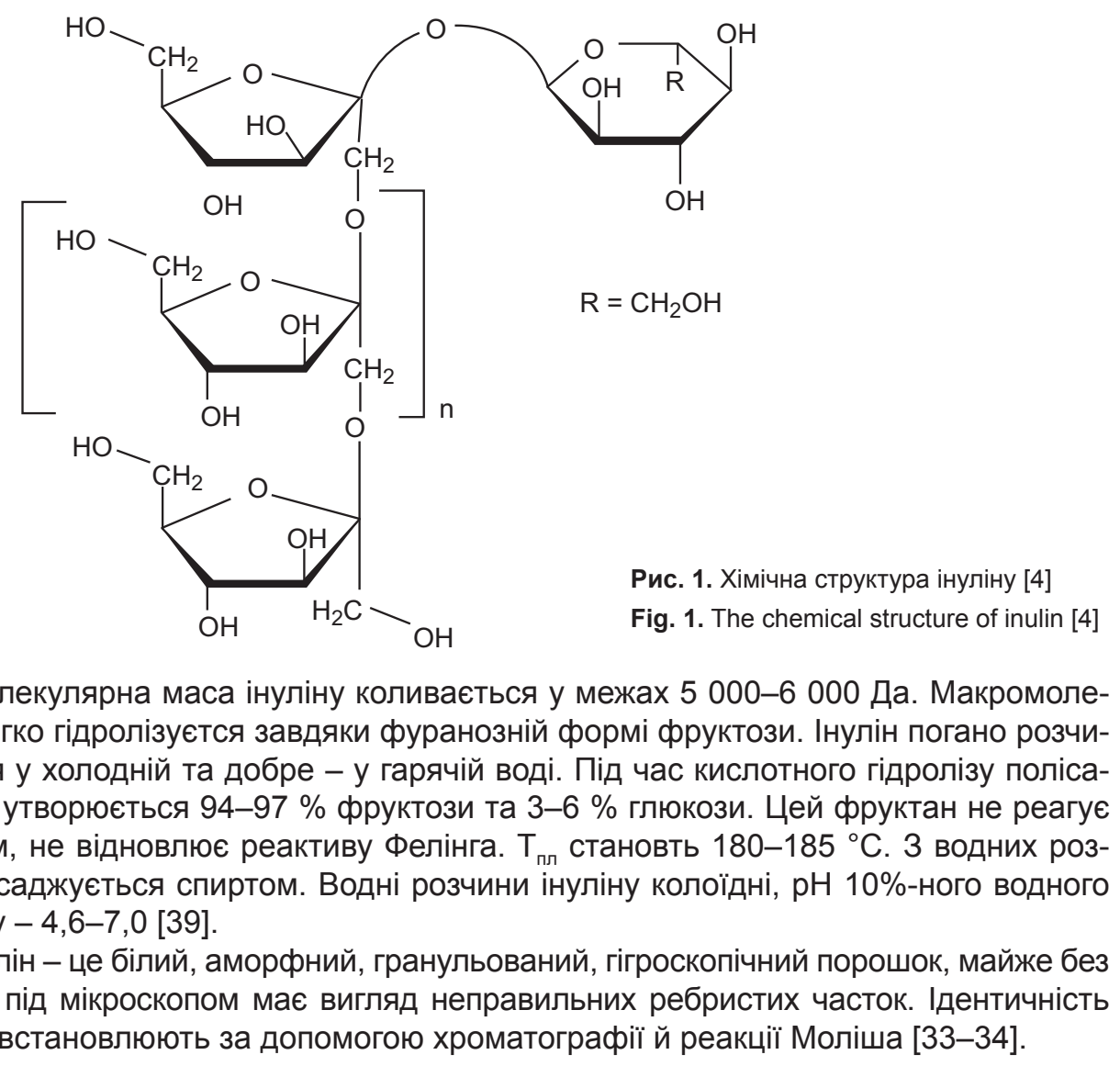

ISSN 1996-4536 (print) • ISSN 2311-0783 (on-line) • Біологічні Студії / Studia Biologica • 2016 • Том 10/№2 • С. 203-214 
Левани - це полімери фруктози, які також є запасними полісахаридами та складаються із багатьох сотень тисяч мономерів (рис. 2). Найкоротшим леваном є 6-кестоза, яка складається із ланцюга з трьох молекул фруктози [7]. Левани синтезують майже всі фррутан-синтезуючі бактерії [8], а також їх виділяють із трансгенного тютюну та коренеплодів [20, 31].

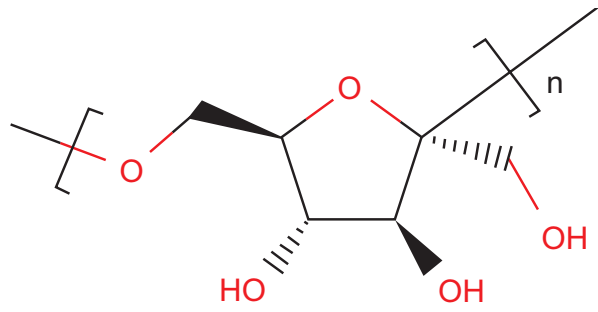

Рис. 2. Хімічна структура мономера левану

Fig. 2. The chemical structure of the levan monomer

Вміст інуліну і ФОС не можна кількісно визначити у розчинній фрракції волокон рослин. Тобто їх визначають безпосередньо за спожитими продуктами харчування. Поточні методи розділення цих сполук недосконалі. Існує проблема для ідентифрікації та кількісного визначення фрруктанів [15]. Найкращим способом для аналізування цих сполук є поєднання різних методів [17].

Класифікація фрруктанів на початкових етапах їхніх досліджень заснована на основі джерела виявлення, не беручи до уваги їхню хімічну структуру, що зумовило хаотичність результатів.

Усі фрруктани за структурою поділяють на п'ять груп [36]:

1. Інуліни, що містять лінійні (2-1) зв'язки залишків $\beta$-D-фрруктози (G1-2F1-2F $\mathrm{F}_{\mathrm{n}}$;

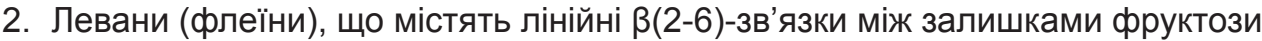
$\left(\mathrm{G} 1-2 \mathrm{~F} 6-2 \mathrm{~F}_{n}\right)$;

3. Фруктани, що містять обидва типи зв'язків - $\beta(2-I)$ та $\beta(2-6)$;

4. Нео-інуліни, що містять у положенні С6 залишок фрруктози, а у положенні C1 глюкозу, продукуючу полімер з $\beta(2-1)$-зв'язками між залишками фрруктози на будь-якому кінці молекули сахарози ( $\left.{ }_{m} \mathrm{~F} 2-1 \mathrm{~F} 2-6 \mathrm{G} 1-2 \mathrm{~F} 1-2 \mathrm{~F}_{\mathrm{n}}\right)$;

5. Нео-левани, що складаються із залишків фрруктози з $\beta(2-I)-$ і $\beta(2-6)$-зв'язками на будь якому кінці молекули сахарози.

Біологічні властивості фруктанів. Фруктани можуть бути стійкими до гідролізу ендогенними травними ензимами у тонкому кишечнику людини і тварин, проте у товстому кишечнику вони метаболізуються деякими анаеробними бактеріями, зброджуються до коротколанцюгових жирних кислот (КЛЖК), газів $\left(\mathrm{H}_{2}, \mathrm{CO}_{2}\right.$ i $\left.\mathrm{CH}_{4}\right)$ і лактату.

Введення фруктанів у раціон харчування тварин впливає на кількість видів бактерій і їхнє співвідношення у товстій кишці. Виявлено збільшену інтенсивність росту біфрідобактерій і стимулювання продукування КЛЖК за дії введення фрруктанів (в основному ФОС). Крім того, у тварин відбувається збільшення маси фекалій і концентрації $\mathrm{H}_{2}$, а також зниження рівня $\mathrm{pH}$. У дослідженнях фрекалій людей спостерігали тільки збільшення кількості біфідобактерій [24].

Додавання фруктанів до їжі щурам впливає на жировий обмін, що призводить до зниження рівня триацилгліцеролів (ТАГ) і холестеролу в сироватці крові [22-30].

ISSN 1996-4536 (print) • ISSN 2311-0783 (on-line) • Біологічні Студії / Studia Biologica • 2016 • Том 10/№2 • С. 203-214 
Проте у людей подібну дію фруктанів не встановлено $[8,14]$. У щурів після прийому фрруктанів у високих концентраціях збільшується поглинання іонів, зокрема $\mathrm{Ca}^{2+}, \mathrm{Mg}^{2+}, \mathrm{Fe}^{2+}[18,27-33]$.

Проведені токсикологічні дослідження на тваринах (генотоксичність, канцерогенність, субхронічна і хронічна токсичність, а також вплив на розвиток плоду) з використанням ФОС дали змогу встановити, що ці цукри не $є$ токсичними. Проте у тварин за умов введення у раціон харчування більше ніж 7,5 \% фруктоолігосахариду „Neosugar” спостерігали діарею. Це призводило до зниження маси тіла, оскільки тварини не компенсували дефіцит енергії у раціоні більш високим споживанням їжі. За введення найвищих доз „Neosugar” упродовж 90 діб спостерігали деякі зміни у структурі кишечника і показників крові [22]. На основі результатів досліджень хронічної токсичності встановлено фрізіологічні зміни, які не вважаються токсикологічно важливими для людини. Прийом приблизно 2,5 г "Neosugar" на кілограм маси тіла (5\% у раціоні) не спричиняє значних фрізіологічних змін у кишечнику. Встановлено, що "Neosugar" не має канцерогенної дії.

Токсикологічний ефект інуліну також не встановлений. Досліджено вплив фрруктанів на вогнище аберантних крипт товстої кишки щурів і мишей. Встановлено, що ФОС та інулін не спричиняють збільшення їхньої загальної кількості у використовуваних моделей, а навпаки, зумовлюють їхнє зниження [12, 23].

Дослідження впливу фруктанів із різною довжиною ланцюга на організм людини упродовж 1-3 тижнів $є$ недостатніми, щоби встановити їх несприятливий ефект. Ввважають, що фрруктани з коротким ланцюгом гірше переносяться організмом людини, ніж ті, що мають довгі ланцюги. Несприятливими ефектами фрруктанів у шлунково-кишковому тракті можуть бути метеоризм, болі в животі, здуття, спазми чи діарея. Проте є також дані, що фруктани сприяють закрепам кишечника. Споживання цих сахаридів (20 г/день) дорослою людиною масою 60 кг, очевидно, не спричиняє побічної дії на організм [19].

Науковий комітет із продовольства Європейської комісії зробив оцінку безпеки ФОС (Neosugar) як харчового інгредієнта. Зроблено висновок, що ФОС не мають суттєвого негативного впливу на організм людини, проте за високих доз (у 5-40 разів вище допустимої) можуть спричиняти шлунково-кишкові розлади з проносним ефектом. Додавання 0,3 і 0,4 г/кг маси тіла для чоловіків і жінок, відповідно, не спричиняє негативного ефректу [10].

Безпечність фрруктанів з довгим карбоновим ланцюгом, зокрема інуліну, потребує більш детального вивчення. Встановлено, що внесення 10\% інуліну у раціон (приблизно 10 г/кг маси тіла молодих щурів) не призводить до втрати маси чи проносу у тварин. Очевидно, інулін краще метаболізується, ніж ФОС, хоча є деякі відмінності у його хімічній структурі, процесі ферментації, впливу на організм [9]. Однак виявлено побічні ефекти (шлунково-кишкові розлади) у людей після прийому фрруктанів як харчових замінників цукру чи жиру [27].

Метаболізм фруктанів кишковою мікрофлооою. Для мікрофрлори рубця жуйних тварин характерні специфічні особливості. Це обумовлено наявністю бактерій, які метаболізують клітковину. Однак целюлозолітичні бактерії, характерні для травного тракту жуйних, також $є$ симбіонтами мікробних асоціацій інших тварин. У сліпій кишці багатьох травоїдних тварин важливу роль відіграють бактерії, що

ISSN 1996-4536 (print) • ISSN 2311-0783 (on-line) • Біологічні Студії / Studia Biologica • 2016 • Том 10/№2 • C. 203-214 
розщеплюють волокна целюлози і геміцелюлози, такі як Bacteroides succinogenes, Ruminococcus flavefaciens, Bacteroides ruminicola та інші.

Відомо, що вміст строго анаеробних видів у кишечнику становить 95-99 \%, тоді як аеробних і факультативно анаеробних - лише 1-5 \%. Через високу кислотність шлункового соку в шлунку міститься невелика кількість мікроорганізмів; в основному це кислотостійка мікрофрлора - лактобактерії, стрептококи, дріжджі, сарцини та ін. [18].

У проксимальних ділянках тонкого кишечника містяться лактобактерії, ентерококи, сарцини, гриби, у більш нижніх відділах наростає кількість біфідобактерій, кишкових паличок. Кількісно вміст представників мікрофлори може відрізнятися у різних особин.

Встановлено, що наявність фруктанів у шлунково-кишковому тракті тварин впливає на кількість видів бактерій і їхнє співвідношення у товстій кишці, зокрема, призводить до збільшення кількості біфрідобактерій. Коротко- та довголанцюгові фруктани є субстратами гідролізу та ферментуються бактеріями у сліпій і ободовій кишці. Специфічність бактеріальної фрерментації залежить від здатності використовувати фрруктани [28].

Молочнокислі біфрідобактерії, крім Bifidobacterium bifidum, мають більшу швидкість росту на фруктоолігосахаридах порівняно зі середовищами, що містять глюкозу, інших представників роду кишкової мікрофрлори (Escherichia coli, Clostridium perfringens), здатних метаболізувати лише глюкозу, але не використовують ФОС. Це підтверджено дослідженнями in vitro, зокрема біфрідобактерії, бактероїди Bacteroids fragilis, представники роду Peptostreptococcus та Klebsiella використовували ФОС (GF2, GF3, GF4 та Neosugar P), проте C. perfringens та E. coli не здатні метаболізувати ці сполуки. Однак нещодавно для ентеробактерій (C. perfringens, E. coli, представників роду Bacteroides і Lactobacillus) встановлено, що вони можуть ферментувати рафтилозу Р95 та інулін [12].

У дослідженні in vitro порівнювали здатність біфідобактерій рости на середовищах із ФОС та інуліном як джерелах карбону. Встановлено, що коротколанцюгові ФОС (СП < 5) є найкращими субстратами для росту цих мікроорганізмів [17].

На основі інших досліджень встановлено, що штами біфідобактерій, виділених від тварин і людини, легко засвоюють ФОС (СП 2-6). Проте мікроорганізми тваринного походження росли на інуліні швидше, порівняно зі штамами, ізольованими від людини [8]. Виявлено, що біфідобактерії кишечника людей, зокрема B. longum, нагромаджували більшу біомасу на середовищі з ФОС, ніж з інуліном. Ця відмінність, імовірно, обумовлена стеричними перешкодами тому, що інулін запобігає контакту з частиною ензиму у клітинних стінках штамів біфідобактерій людини [5].

У дослідженні з використанням кількох систем ферментації встановлено, що біфідобактерії інгібують ріст C. perfringens i E. coli. Молочнокислі бактерії роду Bifidobacterium, Lactobacillus i Lactococcus продукують оцтову та молочну кислоти, які знижують рН у кишечнику і тим самим інгібують ріст бактерій інших видів. Зниження $\mathrm{pH}$, очевидно, є не єдиним механізмом інгібування. Зроблені припущення, що біфідобактерії можуть бути залучені у продукування інших антимікробних речовин [15]. Вибірковість біфрідобактерій до фруктанів обумовлена, ймовірно, наявністю у їхніх клітинах $\beta$-фрруктозидаз, що є селективним фрактором для $\beta(1-2)$ глікозидних зв'язків, які є у фруктанів.

ISSN 1996-4536 (print) • ISSN 2311-0783 (on-line) • Біологічні Студії / Studia Biologica • 2016 • Том 10/№2 • С. 203-214 
Вплив фруктанів на кишкову мікрофлору лабораторних тварин і людей. У літературі наявні лише деякі дані про вплив фруктанів (ФОС) з коротким ланцюгом на кишкову мікрофолору. Наведені дослідження описують вплив ФОС на кількість біфрідобактерій у товстій кишці.

Так, дослідженнями деяких авторі, встановлено, що у мишей, які щоденно отримували 0,29 г ФОС у питну воду впродовж 14 діб і мали вільний доступ до напівочищеної дієти, кількість життєздатних біфідобактерій (колонієутворювальних одиниць, КУО) у фекаліях зі сліпої та ободової кишки мишей, збільшилася до

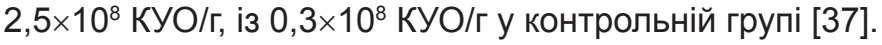

В інших експериментах на щурах також спостерігали значне збільшення кіль-

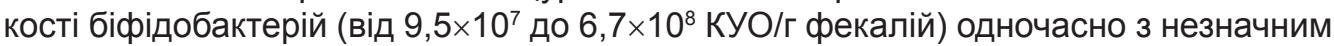

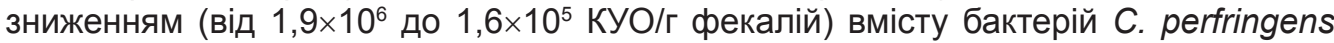
у щурів, які отримували 2\% ФОС в очищеній дієті упродовж 29-35 діб [20]. В інших дослідах на щурах до очищеної дієти вносили додатково $6 \%$ ФОС - NutraFlora або Raftilose упродовж 14 днів. Кількість біфрідобактерій у фрекаліях вимірювали в $\log _{10}$ КУО/г фекалій. Встановлено, що кількість біфідобактерій у щурів, які отримували Nutraflora, були вищими $(9,5)$, ніж у контрольній групі $(8,4)$. У групі, що одержувала Raftilose, кількість цих мікроорганізмів становила 9,4, яка вища, ніж у контрольній групі тварин $(8,9)[2]$.

Однак у інших дослідженнях на щурах, яким за допомогою шлункового зонда упродовж 4 тижнів щоденно вводили $2 \%$ ФОС разом із біфідобактеріями кількістю $10^{8}$ КУО у 1 мл знежиреного молока, жодних суттєвих відмінностей кількості біфрідобактерій та C. perfringens у фрекаліях не встановлено [6]. Під час досліджень модельних стерильних щурів, яким вводили кишкові бактерії, виділені з фрекалій людини, встановлено значне збільшення їхнього вмісту з 7,4 до 9,2 у шкалі $\log _{10}$ бактерій/г фрекалій, після введення у раціон 40 г ФОС (рафтилози Р95) / кг упродовж чотирьох тижнів. Однак не виявлено впливу рафтилози Р95 на інші види бактерій [19]. Використання стерильних щурів дало змогу імітувати умови у товстій кишці людини. Під час застосування такої моделі у кожному дослідженні оцінювали фрізіологічні відмінності між щурами та людиною, зокрема фрактори кислотності, ензими, солі жовчних кислот, моторику кишечника та вплив імунної системи тощо.

У дослідженнях на здорових людях, які отримували 12,5 г ФОС (Actilight 550S) упродовж 12 днів, встановлено значне збільшення кількості біфідобактерій від 7,9 до 9,1 $\log _{10}$ КУО/г фрекалій. Після 20 діб експерименту кількість біфідобактерій відновилася до початкових значень [11].

У дослідженнях на літніх людях, у яких діагностували закрепи, у раціон щоденно додавали 20 г інуліну (Raftiline) упродовж 8 днів із подальшим поступовим збільшенням до 40 г упродовж наступних трьох днів, а потім 40 г на добу ще 8 днів. До і після кожного експерименту обчислено кількість бактерій у шкалі $\log _{10} /$ сухого калу. Встановлено значне збільшення кількості біфрідобактерій до 8,8 і 9,2 у стільці, після введення 20 і 40 г інуліну, відповідно, порівняно із кількістю біфідобактерій $(7,2)$ перед додаванням у раціон цього фруктану. Після прийому 40 г Raftiline на добу упродовж 8 днів виявлено значне зниження кількості ентерококів (від 7,2 до $6,3)$, тоді як вміст клостридій був на сталому рівні $[22,25]$.

В іншому дослідженні 12 здорових осіб, які щодня упродовж 25 днів отримували 4 г ФОС (NutraFlora) виявлено, що середня кількість біфідобактерій становила $7,2 \times 10^{9} \log _{10}$ КУО/сухого калу, що було значно вищим, ніж середня кількість біфідобактерій (2,5×109 $\log _{10}$ КУО/сухого калу) до і після експерименту [21].

ISSN 1996-4536 (print) •ISSN 2311-0783 (on-line) • Біологічні Студії / Studia Biologica • 2016 • Том 10/№2 • C. 203-214 
Під час досліджень 8 здорових осіб, що отримували у раціон харчування 15 г ФОС (Raftiline)/добу упродовж 15 діб, також виявлено, що кількість біфідобактерій у фекаліях була збільшена з 8,8 до 9,5 $\log _{10}$ КУО/фекалій, порівняно з даними перед введенням. У зразках калу встановлено значне зниження кількості представників роду Bacteroides, Clostridium і Fusobacterium. Після 15 діб кількість біфрідобактерій відновилася до початкових значень, проте концентрація представників роду Fusobacterium і Bacteroides значно знизилася. У такому ж дослідженні на чотирьох особах, які щоденно отримували 15 г інуліну (Raftiline) упродовж 15 діб, виявлено подібну закономірність збільшення біфрідобактерій від 9,2 до $10,1 \log _{10}$ КУО/г фекалій, тоді як кількість інших видів не змінювалась [17].

Також було досліджено 23 літніх пацієнти, яким у раціон давали 8 г ФОС (15 г Neosugar G) упродовж двох тижнів. За досліджуваний період встановлено значне збільшення кількості біфідобактерій (від 8,8 до 9,7 $\log _{10}$ КУО/г фрекалій), порівняно з кількістю до введення ФОС. Однак після припинення введення значних змін не спостерігали. Виявлено зниження бактерій роду Clostridium від 7,3 до $6,1 \log _{10}$ КУО/г фекалій, окрім C. perfringens, після початку введення ФОС. Проте на останню добу експерименту встановлено, що кількість цих мікроорганізмів відновилася до початкових значень [14].

Встановлена значно збільшена кількість біфрідобактерій від 8,8 до 9,7 $\log _{10}$ КУО/г фекалій у 23 пацієнтів літнього віку, які щоденно отримували 8 г ФОС упродовж двох тижнів. Однак збільшення кількості лактобацил чи зменшення C. perfringens не виявлено. Незначне збільшення кількості біфідобактерій виявлено через вісім днів після закінчення експерименту. Виявлена сильна негативна кореляція між кількістю біфідобактерій та C. perfringens. У тому ж дослідженні у разі додавання 1, 2 і 4 г ФОС (Neosugar)/добу до їжі пацієнтів упродовж кількох тижнів дало змогу виявити недостовірно підвищену дозозалежну кількість біфрідобактерій [23].

Діючи як пребіотики, інулін і ФОС впливають на ліпідний обмін, знижують концентрацію триацилгліцеролів і ліпополісахаридів. Крім того, вони стимулюють ріст бактерій роду Lactobacillus i Bifidobacterium, зменшуючи наявність патогенів у кишечнику. Інші фруктани, зокрема розчинні олігосахариди, мають подібні карбонові ланцюги до глікопротеїнів і гліколіпідів епітеліальних клітин кишечника. Вони запобігають адгезії патогенних мікроорганізмів, забезпечуючи антимікробний ефект [37].

Дослідження фрруктанів рослин Dasylirion ssp. і Agave tequilana дали можливість встановити, що вони стимулюють продукування КЛЖК і зниження рН товстої кишки. Крім того, додавання фруктанів цих рослин у раціоні мишей зумовлювало збільшення секреції глікополісахаридів і їхніх попередників, проглюкагону мРНК. Це дає змогу припустити, що розклад фруктанів рослинного походження з різною хімічною структурою може обумовлювати продукування інкретинових пептидів у нижній частині кишечника. Фруктани рослин також мають фрізіологічний вплив на метаболізм ліпідів $[13,15]$ і можуть зменшувати окиснювальний стрес [3]. На основі досліджень фруктанів Agave angustifolia і Agave potatorum як пребіотиків встановлено ефект ситості та збільшення глікополісахаридів у кишечнику тварин [4].

Встановлено, що завдяки пробіотичним властивостям фруктанів зменшується ризик розвитку раку [24]. Щоб максимізувати дію пребіотичної сполуки, пребіотик потрібно метаболізувати у дистальному відділі товстої кишки, де переважають протеолітичні ензими і токсичні речовини, такі як аміак, гідрогенсульфід і крезол. Досліджено вплив фрерментації фруктанів агави на комплексний склад мікрофрлори

ISSN 1996-4536 (print) • ISSN 2311-0783 (on-line) • Біологічні Студії / Studia Biologica • 2016 • Том 10/№2 • С. 203-214 
фекалій [39]. Перше клінічне випробування дії фруктанів агави на людях виявилося перспективним, оскільки покращувалася перистальтика кишечника [27]. Інші вуглеводи (глюкоолігосахариди, ізомальтоолігосахариди, лактулози, мананолігосахариди, $\beta$-глюкан, рафінози, олігосахариди сої, трансгалактоолігосахариди та ксилоолігосахариди) вважають пребіотиками [38].

\section{ВИСНОВКИ}

На основі проведеного огляду зарубіжної наукової літератури представлено дані стосовно хімічної структури та біологічних властивостей фруктанів. Наявні результати окремих досліджень впливу різних фруктанів на представників кишкової мікрофрлори лабораторних тварин і людини, проте $є$ недостатньо інформації про метаболізм фруктанів в організмі сільськогосподарських тварин, зокрема жуйних, та про їх можливий вплив на процеси травлення цих тварин. Це є метою наших майбутніх досліджень.

1. Andersen R., Sorensen A. An enzymatic method for the determination of fructans in foods and food products. Comparison of the results by HPAEC-PAD Eur. Food Res. Technol, 1999; 210: 148-152.

2. Banguela A., Hernánde L. Fructans: From natural sources to transgenic plants. Biotecnologia Aplicada, 2006; 23(3): 202-210.

3. Beck E.H., Fettig S., Knake C. et al. Specific and unspecific responses of plants to cold and drought stress. Journal of Bioscience, 2007; 32: 501-510.

4. Cummings J.H., Roberfroid M.B. et al. A new look at dietary carbohydrate: chemistry, physiology and health. Eur. J. Clin. Nutr, 1997; 51: 7-423.

5. Davidson M.H., Maki K.C. Effects of dietary inulin on serum lipids in men and women with hypercholesterolenria. Nutr. Res, 1998; 18: 503-517.

6. Dysseler D., Fockedey J. et al. Determination of inulin and oligofructose in food products. Complex Carbohydrates in Foods. Marcel Dekker Inc. NY, USA. Chap, 1999; 17: 213-227.

7. E. Franco-Robles Implication of fructans in health: immunomodulatory and antioxidant mechanisms. Scientific World Journal, 2015:15.

8. Ellegard L.. Inulin and oligofructose do not influence the absorption of cholesterol, or the excretion of cholesterol, $\mathrm{Ca}, \mathrm{Mg}, \mathrm{Zn}$, Fe or bile acids but increase energy excretion in ileostomy subjects. Eur. J. Clin. Nutr, 1997; 51: 1-5.

9. Fuchs $A$. Current and potential food and non-food applications of fructans. Biochemical Society Transactions, 1991; 19: 555-560.

10. Gomez E., K. Tuohy M., Gibson G. R. In vitro evaluation of the fermentation properties and potential prebiotic activity of Agave fructans. Journal of Applied Microbiology, 2010; 108: 2114-2121.

11. Heuvel E., Muys T., Schaafsma G. Oligofructose stimulates calcium absorption in adolescents. PROFIBRE, Lissabon, 1998: P. 138-139.

12. Heuvel E., Schaafsma G., Muys T. Nondigestible oligosaccharides do not interfere with calcium and nonheme-iron absorption in young, healthy men. Am. J. Clin. Nutr, 1998; 67: 445-451.

13. Hoebregs $H$. Fructans in foods and food products, ion-exchange chromatographic method: Collaborative Study AOAC Int, 1997; 80: 1029-1037.

14. Holscher H.D., Bauer L.L. et al. Gastrointestinal tolerance and utilization of agave inulin by healthy adults. Food \& Function, 2014; 5: 1142-1149.

15. Kim M., Shin H. The water-soluble extract of chicory influences serum and liver lipid concentrations, cecal short-chain fatty acid concentrations and fecal lipid excretion in rats. Biosci. Biotechnol. Biochem, 1998; 128: 1731-1736. 
16. Knudsen K.E. Carbohydrate and lignin contents of plant materials used in animal feedin. Anim. Feed Sci. Technol, 1997; 67: 319-338.

17. Kok N.N., Taper H.S. Oligofructose modulates lipid metabolism alterations induced by a fatrich diet in rats. J. Appl. Tox, 1998; 18: 47-53.

18. Krause D.O., Denman S.E., Mackie R.I. Opportunities to improve fiber degradation in the rumen: microbiology, ecology, and genomics. Microbiol Rev, 2003; 27: 663-693.

19. Lomax A.R., Calder P.C. Prebiotics, immune function, infection and inflammation: a review of the evidence. British Journal of Nutrition, 2009; 101: 633-658.

20. Molck A.M., Poulsen M. Different effect of fructooligosaccharide and inulin on carcinogen-induced aberrant crypt foci in rats. Abstract at the International Conference on Diet and Prevention of Cancer. Tampere, Finland, May 28 - June 1, 1999.

21. Nanthkumar N. N., Newburg D. S., Walker W. A. Role of oligosaccharides and glycoconjugates in intestinal host defense. Journal of Pediatric Gastroenterology and Nutrition, 2000; 30: 23-33.

22. ORAFTI Product book of Raftilose and Raftiline. Version 2. 1997.

23. Pedersen A., Sandstrom $B$. The effect of ingestion of inulin on blood lipids and gastrointestinal symptoms in healthy females. Am. J. Clin. Nutr, 1997; 78: 215-222.

24. Poulsen M., Molck M. Different effect of fructooligosaccharide and inulin on large intestinal physiology in rats. Abstract at the International Conference on Diet and Prevention of Cancer. Tampere, Finland, May 28 - June 1, 1999.

25. Quemener B., Thibault J.-F. Integration of inulin determination in the AOAC method for measurement of total dietary fibre. Coussement Int. J. Biol. Macromol, 1997; 21: 175-178.

26. Quigley M.E., Hudson G.J. Determination of resistant short chain carbohydrates (non-digestible oligosaccharides) using gas-liquid chromatography. Food Chem, 1999; 65: 381-390.

27. Rao C., Chou D., Simi B. Prevention of colonic aberrant crypt foci and modulation of large bowel microbial activity by dietary coffee fiber, inulin and pectin. Carcinogenesis, 1998; 19: 1815-1819.

28. Roberfroid M., Loo J.A., Gibson G.R. Roberfroid M. The bifidogenic nature of chicory inulin and its hydrolysis products. J. Nutr, 1998; 128: 11-19.

29. Safety evaluation of fructan. Tema Nord, 2000. 116 p.

30. Sakaguchi E., Sakoda C. Caecal fermentation and energy accumulation in the rat fed on indigestible oligosaccharides. Br. J. Nutr, 1998; 80: 469-476.

31. Santiago-Garcıa P.A., L'opez M. G. Agavins from Agave angustifolia and Agave potatorumaffect food intake, body weight gain and satiety-related hormones (GLP-1 and ghrelin) in mice. Food\&Function, 2014; 5: 3311-3319.

32. Sayago-Ayerdi S.G., Mateos R.O., Ortiz-Basurto R.I. et al. Effects of consuming diets containing Agave tequilanadietary fibre and jamaica calyces on body weight gain and redox status in hypercholesterolemic rats. Food Chemistry, 2014; 148: 54-59.

33. Schaafsma G., Meuling $W$. Effects of a milk product, fermented by Lactobacillus acidophilus and with fructo-oligosaccharides added, on blood lipids in male volunteers. Eur. J. Clin. Nutr, 1998; 52: 436-440.

34. Scientific Committee on Food. Opinion on Actilight - a fructo oligosaccharide (FOS). Annex IV to document III-5157-97 expressed on 21 March, 1997: 9.

35. Sevenier R., Hall R. High level fructan accumulation in a transgenic sugar beet. Nature Biotech, 1998; 16: 843-846.

36. Shevelev N.S. The physiological role of microbiota in cicatricial digestion. Agricultural Biol, 2005; 6: 9-13. (In Russian)

37. Smeekens S.A. Convert to fructans in sugar beet. Nature Biotech, 1998; 16: 822-823.

38. Slavin J. Fiber and Prebiotics: Mechanisms and Health Benefits. Nutrients, 2013; 5(4): 1417-1435.

39. Stahl B., Linos A. Analysis of fructans from higher plants by matrix-assisted laser desorption/ ionization mass spectrometry. Anal. Biochem, 1997; 246: 195-204.

ISSN 1996-4536 (print) • ISSN 2311-0783 (on-line) • Біологічні Студії / Studia Biologica • 2016 • Том 10/№2 • С. 203-214 
40. Urias-Silvas J. E., Cani P.D., Neyrinck E. A. Physiological effects of dietary fructans extracted from Agave tequilana Gto. and Dasylirion sp. British Journal of Nutrition, 2008; 99: 254261.

\title{
FRUCTANES: CHEMICAL STRUCTURE, BIOLOGICAL PROPERTIES AND METABOLISM BY INTESTINAL MICROFLORA
}

\author{
M. Y. Sabat ${ }^{1}$, R. Y. Iskra ${ }^{2}$ \\ 1 S. Z. Gzhytskyi National University of Veterinary Medicine and Biotechnologies of Lviv \\ 50, Pekarska St., Lviv 79010, Ukraine \\ ${ }^{2}$ Institute of Biological Animals, NAAS of Ukraine, 38, V. Stus St., Lviv 79034, Ukraine \\ e-mail: mariana.sabat@gmail.com
}

This review presents the information about the chemical structure and biological properties of fructanes. The presented results of individual influence research of various fructanes on the representatives of intestinal microflora of the laboratory animals and people. However, there is not enough information about fructanes metabolism in the body of farm animals, including ruminants, and their possible effect on the digestive processes of these animals. The article deals with the importance of fructanes as components of humans and animals diet. It was found out that they affect the metabolism and physiological state of the microorganisms, but their increased numbers in the gute an causo negative effects. Fructooligosaccharides and inulin stimulate growth of the intestine bifid bacteria. Nevertheless, strains of bifid bacteria of animal origin grow on the medium with inulin faster compared to strains isolated from human. The study of influence of orally injected fructooligosaccharides made it possible to detect the stimulating effect of sugars on growth of the bifid bacteria in the intestine of laboratory animals and human. However, these data are not consistent with the effect of fructooligosaccharides in other types of bacteria. The hypothesis was proposed that consumption of fructanes with further increase of the bifid bacteria causes a reduction of clostridia. Therefore analysis of the impact fructanes on other representatives of the intestinal flora of animals shuld be studied.

Keywords: fruktans, metabolism, intestinal microflora, inulin, levan.

\section{ФРУКТАНЫ: ХИМИЧЕСКАЯ СТРУКТУРА, БИОЛОГИЧЕСИКЕ СВОЙСТВА И МЕТАБОЛИЗМ КИШЕЧНОЙ МИКРОФЛОРЫ}

\section{М. Я. Сабат 1 , Р. Я. Искра}

1 Львовский национальный университет ветеринарной медицины и биотехнологий имени С. З. Гжицкого, ул. Пекарская, 50, Львов 79010, Украина

${ }^{2}$ Институт биологии животных НААН Украины, ул. В. Стуса, 38, Львов 79034, Украина e-mail: mariana.sabat@gmail.com

В литературе представлены данные зарубежных авторов по химической структуре и биологических свойствах фруктанов. Представлены результаты отдельных исследований влияния различных фруктанов на представителей кишечной микрофрлоры лабораторных животных и людей, однако недостаточно информации

ISSN 1996-4536 (print) • ISSN 2311-0783 (on-line) • Біологічні Студії / Studia Biologica • 2016 • Том 10/№2 • C. 203-214 
о метаболизме фруктанов в организме сельскохозяйственных животных, в частности жвачных, и их возможное влияние на процессы пищеварения этих животных, ляжет в основу будущих исследований авторов. В статье раскрыта важность фруктанов как компонентов рациона питания человека и животных. Установлено, что они влияют на метаболизм и физиологическое состояние макроорганизма, однако увеличенное их количество в кишечнике вызывает негативные эффректы. Фруктоолигосахариды и инулин стимулируют рост бифидобактерий кишечника. Однако штаммы бифидобактерий животного происхождения растут на среде с инулином быстрее, по сравнению со штаммами, изолированными от человека. Исследование влияния перорально введенных фруктоолигосахаридов позволило выявить стимулирующее действие этих сахаров на рост бифидобактерий в кишечнике лабораторных животных и человека. Однако эти данные не согласуются с эффектом фруктоолигосахаридов для других видов бактерий. Предложена гипотеза, что потребление фруктанов с последующим увеличением бифидобактерий приводит к уменьшению количества клостридий. Поэтому в дальнейшем исследователям необходимо проанализировать влияние фруктанов на других представителях кишечной микрофрлоры животных.

Ключевые слова: фрруктаны, метаболизм, кишечная микрофлора, инулин, ливан.

Одержано: 12.07.2016

ISSN 1996-4536 (print) • ISSN 2311-0783 (on-line) • Біологічні Студії / Studia Biologica • 2016 • Том 10/№2 • С. 203-214 